"Vol 3, No 1 (2019): July - Desember"

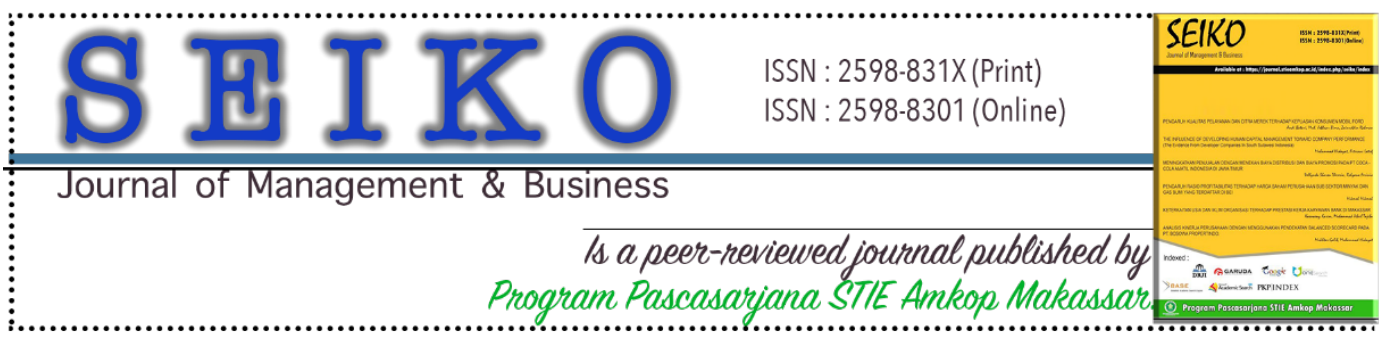

How to Cite:

T.Jibril. (2019). PENINGKATAN AKSESIBILITAS TERHADAP PERBANKAN MELALUI PELATIHAN PENYUSUNAN LAPORAN KEUANGAN BAGI UMKM DI KABUPATEN BONE. SEIKO : Journal of Management \& Business, 3(1), 1- 12.

\title{
PENINGKATAN AKSESIBILITAS TERHADAP PERBANKAN MELALUI PELATIHAN PENYUSUNAN LAPORAN KEUANGAN BAGI UMKM DI KABUPATEN BONE
}

\section{Increasing Accessibility Toward Banking Through Training for the Development of Financial Statements for UMKM at Bone District}

Muhammad Jibril Tajibu

Fakultas Ekonomi dan Bisnis Universitas Hasanuddin

Email : jibril@unhas.ac.id

\section{Bachtiar Mustari}

Fakultas Ekonomi dan Bisnis Universitas Hasanuddin

Email: bachtiar@unhas.ac.id

\section{Baso Siswadarma}

Fakultas Ekonomi dan Bisnis Universitas Hasanuddin

Email: basosiswadarma@gmail.com

\section{Kasnaeny Karim}

Institut Bisnis dan Keuangan Nitro Makassar

Email: kasnaeni.k@nitromks.ac.id 
"Vol 3, No 1 (2019): July - Desember"

\begin{abstract}
ABSTRAK
Kabupaten Bone memiliki banyak Usaha Mikro Kecil dan Menengah (UMKM), namun berdasarkan penelusuran awal, mereka tidak memiliki kemampuan untuk memenuhi salah satu syarat dalam pengajuan KUR yakni membuat Laporan Keuangan, baik secara manual maupun dengan menggunakan teknologi komunikasi, sementara dengan menggunakan teknologi maka pembuatan laporan keuangan itu akan menjadi lebih mudah. Untuk itu, kegiatan ini berupaya hendak mengatasi permasalahan yang ada pada UMKM, dalam rangka mendukung upaya peningkatan ekonomi masyarakat yang tergabung dalam koperasi melalui perluasan jaringan pemasaran produk. Diharapkan nantinya UMKM mampu meningkatkan skala usaha mereka yang akan berdampak terhadap peningkatan taraf hidup, melalui pemanfaatan teknologi informasi dan komunikasi.
\end{abstract}

Dengan demikian, tujuan kegiatan ini adalah meningkatkan kemampuan mengakses dana perbankan, untuk menciptakan kesejahteraan masyarakat desa mitra. Untuk itu, tujuan khususnya ialah (1) Meningkatkan keterampilan UMKM dalam membuat Laporan Keuangan (2). Meningkatkan keterampilan UMKM dalam penggunaan program TIK dalam menyusun laporan keuangan. (3) Pelatihan dalam melakukan evaluasi dan monitoring (4) Mengubah pola pikir masyarakat terkait teknologi informasi. Hasil yang dicapai adalah: (a) kemampuan UMKM melakukan pembuatan laporan keuangan berbasis TIK, (b) bertambahnya pengetahuan dalam melakukan kegiatan pembukuan.

Kata-kata Kunci : Laporan Keuangan, UMKM, Kredit Usaha Rakyat, Teknologi Informasi dan Komunikasi .

\begin{abstract}
Bone Regency has a lot of Micro, Small and Medium Enterprises (UMKM), but based on initial search, they do not have the ability to fulfill one of the requirements in submitting People's Business Credit (KUR), which is to make Financial Reports, both manually and using communication technology, while using technology, the making of financial statements will be easier. Thus, this activity seeks to overcome the problems that exist in UMKM, in order to support efforts to improve the economy of the people who are members of cooperatives through the expansion of product marketing networks. It is expected that later UMKM will be able to increase the scale of their businesses which will have an impact on improving living standards, through the use of information and communication technology.
\end{abstract}

Thus, the purpose of this activity is to improve the ability to access banking funds, to create the welfare of partner village communities. For this reason, the specific objectives are (1) Improving UMKM skills in preparing Financial Statements (2). Improve UMKM skills in using ICT programs in preparing financial reports. (3) Training in evaluating and monitoring (4) Changing the mindset of the community related to information technology. 
"Vol 3, No 1 (2019): July - Desember"

The results achieved are: (a) the ability of UMKM to produce ICT-based financial reports, (b) the increased knowledge in carrying out bookkeeping activities

Keywords : Financial Statements, UMKM, People's Business Credit, Information and Communication Technology.

\section{PENDAHULUAN}

Pemerintah menggalakkan tumbuhnya Usaha Mikro Kecil Menengah (UMKM), sebagai salah satu pilar ekonomi Indonesia mengingat kapasitas UMKM sebagai buffer menyerap tenaga kerja terbesar di Indonesia, dan sektor yang telah terbukti efektif mendukung pertumbuhan ekonomi. Jumlah Usaha Mikro Kecil dan Menengah (UMKM) di Indonesia terus bertambah setiap tahunnya. Berdasarkan data Badan Pusat Statistik (BPS) tahun 2015, kontribusi sektor UMKM terhadap Produk Domestik Bruto (PDB) mencapai 60,34\%.

PDB dari sektor ini meningkat dari $57,84 \%$ menjadi $60,34 \%$ dalam 5 tahun terakhir. Serapan tenaga kerja pada sektor ini juga meningkat dari $96,99 \%$ menjadi $97,22 \%$ pada periode yang sama. Pada tahun 2014 , jumlah pelaku UMKM di Indonesia mencapai sekitar 57,9 juta. Namun dari sekitar 62 juta UMKM, baru sekitar 17,6 juta usaha yang sudah mampu mengakses pembiayaan bank melalui program KUR, selebihnya atau sekitar 44 juta usaha belum akses ke lembaga keuangan. Hal inipun tampak pada UMKM yang ada di kabupaten Bone. Pemerintah telah menjalankan program KUR sejak 2007, akan tetapi jangkauan ke usaha mikro masih sangat terbatas. Bank sulit masuk ke segmen kelompok usaha yang membutuhkan modal atau pembiayaan skala kecil (ultra) yang tidak memiliki aset untuk diagunkan. Hal yang sama juga dinyatakan oleh http://jogja.tribunnews.com, oleh Pawestri (2018) bahwa masih cukup banyak jumlah usaha mikro yang tidak terfasilitasi oleh KUR yang jumlahnya mencapai 44 juta usaha lebih atau 72.1 persen dari jumlah UMKM. Tapi itu belum bisa men-cover UMKM Nasional yang jumlahnya 61 juta tadi baru sekitar 17 juta yg bisa ter-cover. Sisanya 44 juta belum bisa tercover KUR karena belum memenuhi syarat.

Salah satu alasan rendahnya aksesibilitas UMKM terhadap lembaga keuangan adalah kurangnya laporan keuangan UMKM yang bisa menjadi acuan bagi perbankan untuk menilai kapasitas UMKM dalam pengembalian pinjaman.Hal ini sejalan dengan pernyataan Maith (2013) yang menguti pendapat Kasmir (2008:7) bahwa laporan keuangan adalah laporan yang menunjukkan kondisi keuangan perusahaan pada saat ini atau dalam suatu periode tertentu. Sementara Susilo (2009:10) menyatakan bahwa laporan keuangan adalah hasil akhir dari proses akuntansi yang memuat informasi-informasi dan memberikan keterangan-keterangan mengenai data ekonomi perusahaan yang terdiri dari daftar-daftar yang menunjukan posisi keuangan dan hasil kegiatan perusahaan untuk satu periode yang meliputi neraca, laporan laba rugi dan laporan perubahan keuangan. Oleh sebab itu UMKM harus memiliki laporan keuangan arus kas dan rugi laba agar usaha UMKM mampu 
"Vol 3, No 1 (2019): July - Desember"

berkembang dan tumbuh seperti industri lain. Untuk itu diperlukan pelatihan bagi UMKM untuk menyusun laporan keuangannya sendiri.

Penyusunan laporan keuangan harus menjadi bagian dari aktivitas wirausaha. Laporan keuangan ini digunakan untuk mengevaluasi, melakukan pengambilan keputusan, hingga sarana untuk mengembangkan usaha ke depan. Seperti diketahui kelemahan UMKM ialah lemahnya akses modal, rendahnya mutu SDM, dan akses teknologi yang masih rendah. Sebagai acuannya terdapat sekitar 62,9 juta pelaku usaha UMKM di Indonesian namun kelasnya jauh di bawah UMKM di negara lain dan hanya sekitar $20 \%$ dapat mengakses perbankan atau masih ada 80 persen yang belum bankable. Untuk mengatasi persoalan hulu UMKM, pemerintah terus mengupayakan peningkatan kualitas, pengembangan disain, dan juga peningkatan kepuasan pelanggan di bidang pasar. Struktur perekenomian Kabupaten Bone masih didominasi oleh sektor-sektor yang ada pada Kategori A yaitu Pertanian, Kehutanan, dan Perikanan. Hal tersebut dapat dilihat dari kontribusi sektorsektor yang ada pada Kategori A terhadap pembentukan total PDRB Kabupaten Bone tahun 2017 yaitu sebesar 49,37 persen. Kabupaten Bone adalah salah satu kabupaten di pesisir timur Provinsi Sulawesi Selatan yang berjarak $125 \mathrm{~km}$ dari Kota Makassar. Bone merupakan kabupaten terluas ketiga yang ada di Provinsi Sulawesi Selatan dengan jumlah kecamatan sebanyak 27 kecamatan. Luas wilayah Kabupaten Bone adalah 4.559 km2 dengan luas wilayah terluas berada di Kecamatan Bontocani dan luas wilayah terkecil berada di Kecamatan Tanete Riattang. Penduduk Kabupaten Bone berdasarkan proyeksi penduduk tahun 2017 sebanyak 751.026 jiwa yang terdiri atas 358.889 jiwa penduduk laki-laki dan 392.137 jiwa penduduk perempuan. Dibandingkan dengan proyeksi jumlah penduduk tahun 2016, penduduk Bone mengalami pertumbuhan sebesar 0,54 persen dengan masing-masing persentase pertumbuhan penduduk laki-laki sebesar 0,62 persen dan penduduk perempuan sebesar 0,48 persen. Sementara itu besarnya angka rasio jenis kelamin tahun 2017 penduduk laki-laki terhadap penduduk perempuan sebesar 91,52.

Jumlah unit usaha di Kabupaten Bone tahun 2016 tercatat 6.971 dan pada tahun 2017 menurun menjadi 2.239. Adapun jumlah tenaga kerja yang diserap pada tahun 2016 sebanyak 21.337 menurun menjadi 2.608 orang pada tahun 2017. Jumlah perusahaan yang mendapatkan Surat Izin Usaha Perdagangan menurut golongan usaha di Kabupaten Bone sebanyak 987 usaha pada tahun 2017 yang terdiri dari, usaha perdagangan kecil tercatat 895 usaha, usaha perdagangan menengah tercatat 40 usaha, dan usaha perdagangan besar 3 usaha. Dari data yang dipublikasi BPS (2018), disampaikan bahwa terjadi penurunan kegiatan yang dilihat dari jumlah unit usaha di Kabupaten Bone tahun 2016 tercatat 6.971 dan pada tahun 2017 menurun menjadi 2.239. Adapun jumlah tenaga kerja yang diserap pada tahun 2016 sebanyak 21.337 menurun menjadi 2.608 orang pada tahun 2017. Salah satu faktor yang dapat menjadi pendorong berkurangnya jumlah usaha itu ialah besarnya halangan masuk ke dalam pasar (barrier to entry) berupa akses terhadap dana perbankan yang rendah. Salah satu penyebabnya adalah rendahnya kemampuan pelaku usaha kecil dalam membuat laporan 
keuangan yang kredibel yang dapat dijadikan acuan bagi perbankan untuk menyalurkan kreditnya. Berdasarkan penelusuran awal, mereka tidak memiliki kemampuan untuk memenuhi salah satu syarat dalam pengajuan KUR yakni membuat Laporan Keuangan, baik secara manual maupun dengan menggunakan teknologi komunikasi, sementara dengan menggunakan teknologi maka pembuatan laporan keuangan itu akan menjadi lebih mudah.

Dengan demikian masalah yang ingin dipecahkan adalah Bagaimana meningkatkan kemampuan dalam mengakses perbankan untuk mendapatkan modal usaha, melalui kemampuan pembuatan Laporan Keuangan berbasis teknologi informasi dan komunikasi.

\section{KAJIAN PUSTAKA}

\section{a. Laporan Keuangan}

Untuk mengetahui kondisi keuangan perusahaan dapat dilakukan dengan melihat Laporan Keuangan perusahaan. Laporan keuangan memberikan gambaran mengenai posisi keuangan yang berasal dari kinerja perusahaan dalam menghasilkan laba. Posisi keuangan perusahaan dapat terlihat dari neraca yang menggambarkan posisi aktiva, kewajiban dan modal pada saat tertentu. Menurut Munawir (2004:2) bahwa "Laporan Keuangan merupakan hasil dari proses akuntansi yang pada dasarnya dapat digunakan sebagai alat komunikasi antara data keuangan atau aktivitas suatu perusahaan dengan pihak yang berkepentingan dengan data atau aktivitas dari perusahaan tersebut."

Tujuan dari Laporan Keuangan menurut Trianto (2017) yang mengutip pendapat Kasmir, yaitu:

1. Memberikan informasi tentang jenis dan jumlah aktiva (harta) yang dimiliki perusahaan pada saat ini.

2. Memberikan informasi tentang jenis dan jumlah kewajiban dan modal yang dimiliki perusahaan pada saat ini.

3. Memberikan informasi tentang jenis dan jumlah pendapatan yang diperoleh pada suatu periode tertentu.

4. Memberikan informasi tentang jumlah biaya dan jenis biaya yang dikeluarkan perusahaan dalam suatu periode tertentu.

5. Memberikan informasi tentang perubahan-perubahan yang terjadi terhadap aktiva, pasiva, dan modal perusahaan.

6. Memberikan informasi tentang kinerja manajemen perusahaan dalam suatu periode.

7. Memberikan informasi tentang catatan-catatan atas laporan keuangan.

8. Informasi keuangan lainnya.

Laporan keuangan memberikan informasi yang sangat penting dalam menilai perkembangan suatu perusahaan dan dapat pula memberikan informasi mengenai keadaan keuangan perusahaan di masa lalu, masa kini, serta kemungkinan 
"Vol 3, No 1 (2019): July - Desember"

kondisi keuangan di masa yang akan datang. Bagi perbankan sebagai pihak pemberi kredit dengan adanya laporan keuangan ini, maka dapat digunakan sebagai acuan dalam pengambilan keputusan dalam menyalurkan dana kepada pihak yang membutuhkan.

Dalam pengambilan keputusan penyaluran kredit, tidak tidak cukup hanya melihat laporan keuangan (Sagita, 2017) hal ini disebabkan laporan keuangan baru dapat menghasilkan informasi jika telah dilakukan analisis laporan keuangan. Inilah yang kemudian menjadi acuan atau menjadi dasar pertimbangan dalam pengambilan keputusan. Analisis dilakukan dilakukan dengan perhitungan rasio yakni analisis rasio keuangan.

Analisis rasio keuangan digunakan untuk membantu mengetahui kinerja keuangan perusahaan, apakah baik atau tidak. Analisis rasio keuangan terdiri dari rasio likuiditas, profitabilitas, solvabilitas, dan aktivitas. Likuiditas merupakan rasio yang memperlihatkan tingkat kemampuan perusahaan dalam memenuhi kewajiban keuangan yang harus segera dipenuhi, atau tingkat kemampuan perusahaan dalam memenuhi kewajiban segera saat ditagih. Profitabilitas merupakan rasio yang menunjukkan kemampuan perusahaan dalam menghasilkan laba selama periode tertentu. Solvabilitas menunjukan tingkat kemampuan perusahaan dalam memenuhi kewajiban keuangan manakala perusahaan tersebut dilikuidasikan, baik kewajiban keuangan jangka pendek maupun jangka panjang. Rasio aktivitas menunjukkan tingkat kemampuan perusahaan dalam mengukur keefektifan perusahaan menggunakan sumber dayanya. (Kesuma, 2019, dan Trianto, 2017)

\section{b. Permintaan Kredit Perbankan}

Kredit merupakan pemberian prestasi berupa uang atau barang (prestasi) dengan balasan prestasi (kontra prestasi) yang akan terjadi pada waktu mendatang. Yang dimaksud dengan prestasi disini adalah jumlah uang atau barang yang diberikan oleh bank selaku kreditur kepada peminjam selaku. Sedangkan kontraprestasi dimaksudkan sebagai sejumlah uang yang harus diberikan oleh debitur kepada kreditur sebagai imbalam atas pinjaman yang diberikan (bunga). Semakin tinggi tingkat suku bunga, semakin besar pula jumlah uang yang harus dikeluarkan oleh debitur (Akmal, dkk, 2014).

Selanjutnya menurut Akmal, dkk (2014), Data Bank Indonesia menunjukkan terjadi peningkatan secara bertahap pada penyaluran kredit secara bertahap. Secara umum peningkatan cukup tinggi terjadi pada kredit modal kerja dan kredit konsumsi, namun terjadi penurunan pada kredit investasi. Pertumbuhan kredit pada triwulan IV 2018 tercatat sebesar 8,2\% atau lebih tinggi dibandingkan triwulan sebelumnya yang sebesar $7,5 \%$. Pertumbuhan bersumber dari kredit investasi korporasi di tengah melambatnya kredit konsumsi rumah tangga. Dari sisi DPK, pertumbuhan akseleratif DPK hingga akhir tahun 2018 mencapai 6,3\% dibandingkan triwulan III 2018 yang mencapai 6,1\% (yoy), sejalan dengan DPK korporasi yang lebih tinggi di tengah moderasi DPK rumah tangga. Sementara dari sisi kabupaten/kota, Makassar sebagai pangsa tertinggi (65\%), tumbuh meningkat mencapai $4,3 \%$. Dengan demikian pertambahan penyaluran kredit ke masyarakat dapat dimaknai bahwa permintaan kredit mengalami peningkatan. 
Secara teori faktor yang mempengaruhi permintaan kredit diantaranya adalah tingkat suku bunga pinjaman. Selain itu, terjadinya inflasi juga menyebabkan munculnya permintaan kredit. Menurut Akmal, dkk (2014) terjadinya inflasi menyebabkan masyarakat membutuhkan lebih banyak uang akibat harga barangbarang yang meningkat, sehingga mengajukan permintaan kredit ke bank.

\section{c. Usaha Mikro Kecil Mengengah (UMKM)}

Usaha mikro kecil menengah atau (UMKM) merupakan usaha ekonomi produktif yang dimiliki perorangan maupun badan usaha sesuai dengan kriteria yang ditetapkan oleh Undang-undang No. 20 tahun 2008. Usaha Mikro adalah usaha produktif milik orang perorangan dan/atau badan usaha perorangan yang memenuhi kriteria Usaha Mikro sebagaimana diatur dalam Undang-Undang ini. Kriteria asset: Maksimal Rp 50 Juta, kriteria Omzet: Maksimal Rp 300 juta rupiah.

Usaha Kecil adalah usaha ekonomi produktif yang berdiri sendiri, yang dilakukan oleh orang perorangan atau badan usaha yang bukan merupakan anak perusahaan atau bukan cabang perusahaan yang dimiliki, dikuasai, atau menjadi bagian baik langsung maupun tidak langsung dari usaha menengah atau usaha besar yang memenuhi kriteria Usaha Kecil sebagaimana dimaksud dalam Undang-Undang ini. Kriteria asset: Rp 50 juta - Rp 500 juta, kriteria Omzet: Rp 300 juta - Rp 2,5 Miliar rupiah.

Usaha Menengah adalah usaha ekonomi produktif yang berdiri sendiri, yang dilakukan oleh orang perseorangan atau badan usaha yang bukan merupakan anak perusahaan atau cabang perusahaan yang dimiliki, dikuasai, atau menjadi bagian baik langsung maupun tidak langsung dengan usaha Kecil atau usaha besar dengan jumlah kekayaan bersih atau hasil penjualan tahunan sebagaimana diatur dalam Undang-Undang ini. Kriteria asset: 500 juta - Rp 10 Miliar, kriteria Omzet: >Rp 2,5 Miliar - Rp 50 Miliar rupiah (Go UKM.id, 2019)

\section{METODOLOGI PENELITIAN}

Kegiatan ini dilakukan dengan pendekatan kualitatif dirangkaikan dengan pengamatan dan pelatihan. Kegiatan awal dilakukan dengan mengumpulkan informasi melalui wawancara, sehingga dapat menentukan metode yang tepat dalam memecahkan masalah. Adapun urutan kegiatan sebagai berikut:

\section{PERMASALAHAN MITRA UMKM}

- Masih rendahnya sektor UMKM dalam menyerap KUR.

- Belum memiliki pengetahuan dalam menyusun laporan keuangan sederhana sesuai standar perbankan

- Kemajuan TIK namun belum dimanfaatkan oleh UMKM untuk meningkatkan kinerjanya terkait pelaporan keuangan.

- UMKM belum dapat melakukan evaluasi usahanya (monitoring dan evaluasi) karena tidak memiliki laporan keuangan yang standar.

- UMKM belum melakukan pemisahan antara uang pribadi dengan uang usaha. 
"Vol 3, No 1 (2019): July - Desember"

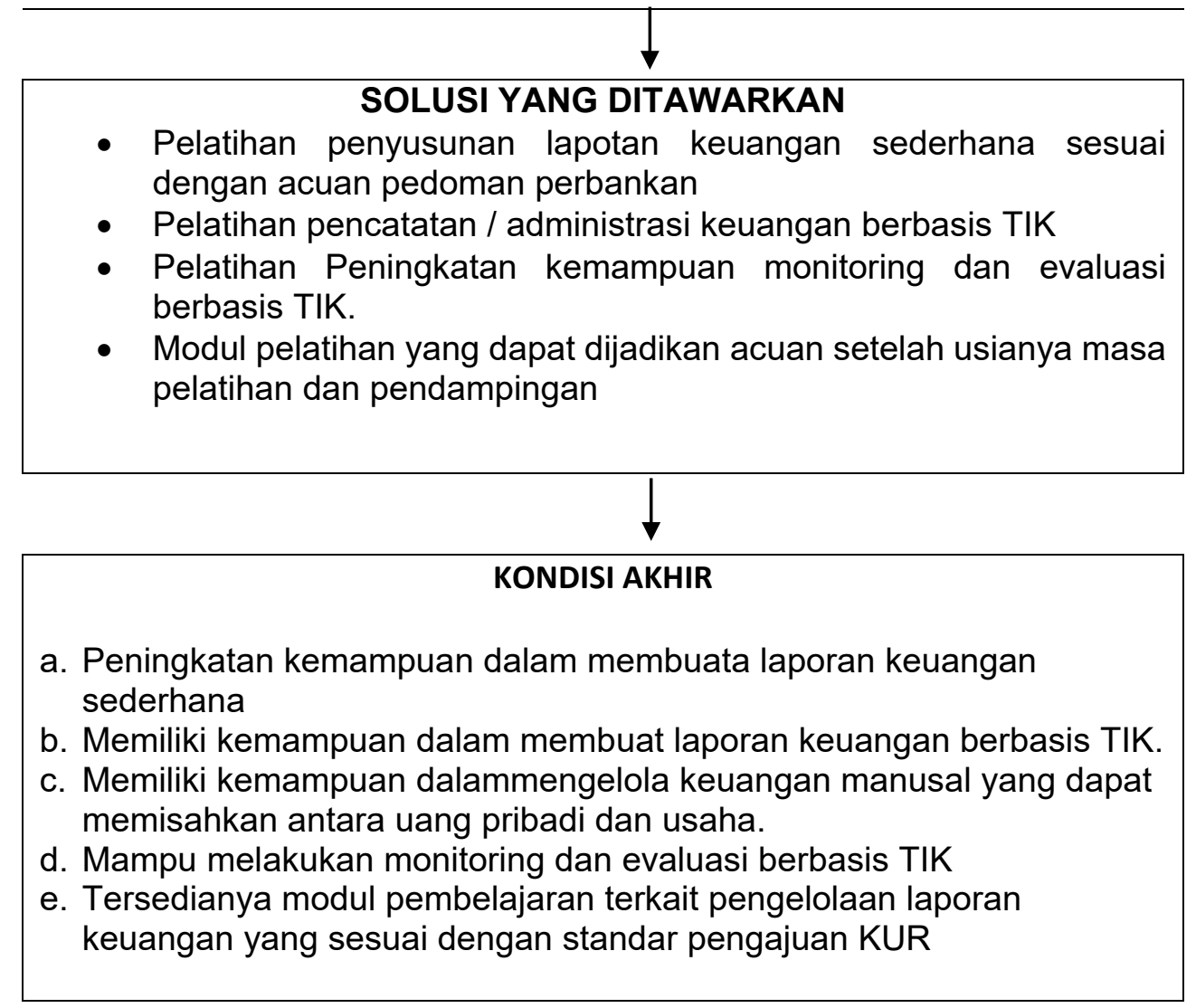

Kegiatan dirancang sejak bulan Februari 2019 dan pelaksanaannya dilakukan mulai bulan Maret sampai dengan bulan Agustus 2019. Perancangan dilakukan dengan Tim dan Mitra yang menjadi sampel.

Sampel kegiatan sejumlah 24 orang pengelola keuangan UMKM di Kabupaten Bone. UMKM ini terdiri dari UMKM Makanan, UMKM Minuman, UMKM kerajinan tangan, UMKM Manufaktur, dan UMKM Pertanian dan Perikanan. Kriteria penentuan sampel berdasarkan kemampuan peserta menggunakan media android. Dari interaksi di kelas, diperoleh informasi bahwa pelatihan dengan berbasis smartphone baru pertama kali diikuti. Seluruh peserta sudah mahir menggunakan perangkat smartphone, sehingga kendala teknis seperti instalasi program tidak menemui kendala sama sekali.

Praktek penggunaan smarphone dalam penyusunan laporan Keuangan diajarkan berdasarkan Pedoman Teknis Pencatatan Keuangan yang dikembangkan oleh Bank Indonesia bernama Si Apik. SI APIK merupakan Aplikasi Pencatatan Informasi Keuangan, dimana si Apik ini digunakan untuk mencatat keuangan secara mobile menggunakan smartphone berbasis Android dan iOS. Aplikasi ini dikembangkan dengan mengacu kepada Pedoman Pencatatan Transaksi Keuangan yang disusun oleh Bank Indonesia bersama Akuntansi Indonesia serta Standar Akuntansi Keuangan Entitas Mikro, Kecil, dan Menengah (SAK EMKM). 
"Vol 3, No 1 (2019): July - Desember"

\section{HASIL}

Dari hasil pengamatan langsung, wawancara, dan tanya jawab serta pelatihan yang diberikan, maka terlihat bahwa terdapat peningkatan pengetahuan dan keterampilan pengelolaan keuangan, dalam menghasilkan Laporan Keuangan yang sesuai Pernyataan Standar Akuntansi Keuangan (PSAK). Hasil lain yang terlihat adalah peserta/sampel dapat menguasai cara pengelolaan keuangan baru yang berbasis smartphone dengan platform Android yang menghasilkan empat laporan keuangan, yakni: Neraca, Laporan Laba Rugi, Laporan Arus Kas, dan Laporan Perubahan Modal.

\section{PEMBAHASAN}

Mayoritas penduduk Kabupaten Bone memiliki kegiatan bertani/berkebun, sehingga wajarlah jika kegiatan ekonominya bercorak pertanian atau agroindustri. Hasil pertanian tersebut dijual langsung dan adapula yang dipasarkan melalui koperasi.

Dari data yang dipublikasi oleh BPS (2018) bahwa terjadi penurunan kegiatan yang dilihat dari jumlah unit usaha di Kabupaten Bone, dimana tahun 2016 tercatat 6.971 unit dan pada tahun 2017 menurut menjadi 2.239 unit. Salah satu faktor yang menjadi pendorong berkurangnya jumlah usaha itu ialah besarnya halangan masuk ke dalam pasar (barrier to entry) berupa akses terhadap dan perbankan yang rendah. Salah satu penyebabnya adalah rendahnya kemampuan pelaku usaha kecil dalam membuat laporan keuangan yang kredibel dan dapat dijadikan acuan bagi perbankan untuk menyalurkan kreditnya.

Berdasarkan penelusuran awal, bahwa UMKM tidak memiliki kemampuan untuk memenuhi syarat dalam pengajuan Kredit Usaha Rakyat (KUR) yakni laporan keuangan, baik secara manual maupun dengan menggunakan teknologi komunikasi, sementara apabila menggunakan teknologi maka pembuatan laporan keuangan akan menjadi lebih mudah.

Setelah melakukan wawancara secara langsung dan pelatihan, maka terdapat dua manfaat yang didapatkan, yakni:

a. Adanya peningkatan kemampuan dan keterampilan pengelolaan keuangan dalam menghasilkan Laporan Keuangan yang sesuai dengan Pernyataan Standar Akuntansi Keuangan (PSAK).

b. Dikuasainya cara pengelolaan keuangan baru yang berbasis smartphone dengan plantform Android, yang menghasilkan empat Laporan Keuangan yakni Neraca, Laporan Laba Rugi, Laporan Arus Kas, dan Laporan Perubahan Modal.

Para pimpinan dan bagian keuangan UMKM sangat antusias mengikuti pelatihan, hal ini disebabkan karena metode penggunaan smartphone dalam 
"Vol 3, No 1 (2019): July - Desember"

pengelolaan keuangan merupakan hal yang baru. Selain itu peserta juga membutuhkan cara-cara baru yang secara praktis dapat dimanfaatkan dalam pengelolaan keuangan di UMKM masing-masing.

Dengn kemampuan membuat laporan keuangan melalui smartphone, maka UMKM sudah dapat membuat laporan keuangan secara lebih cepat dan sesuai dengan persyaratan perbankan dalam menyalurkan dananya. Hal ini disebabkan program SI APIK merupakan sistem yang sudah sesuai dengan kebutuhan perbankan untuk menilai apakah dengan berdasarkan laporan keuangannya, maka sudah layak diberi kredit usaha. Responden menjelaskan bahwa dengan kemampuan mengakses SI APIK maka UMKM tidak memiliki kendala dalam menyusu laporan keuangan mereka yang sudah terstruktur sesuai persyaratan perbankan.

\section{SIMPULAN}

Kemampuan responden dalam mengakses dana perbankan telah meningkat, yang diakibatkan oleh kemampuan memanfaatkan smartphone dalam menyusun laporan keuangan. Dengan penggunaan smartphone maka pelaku UMKM dapat mengakses laporan keuangan yang standar dan sesuai yang diharapkan oleh perbankan dengan memanfaatkan program Bak Indonesia yang bernama SI APIK.

Saran yang dapat diberikan kepada pelakuk UMKM di Kabupaten Bone adalah rata-rata UMKM belum memiliki sumberdaya yang cakap dalam melaksanakan pengelolaan laporan keuangan secara daring. Untuk itu diperlukan pelatihan pada UMKM yang belum mampu mengakses sistem SI APIK yang dapat mempermudah pelaporan.

\section{REFERENSI}

Akmal, Fahmi, Abubakar Hamzah, dan Raja Masbar, 2014, Faktor-Faktor Yang Mempengaruhi Permintaan Kredit Pada Bank Umum di Aceh, Jurnal Ilmu Ekonomi Pascasarja, Universitas Syiah Kuala, Volume 2 Nomor 4, Hal. 45-56

Andari, Dwi Wahyu, Musa Hubeis, dan Hartrisari Hardjomijodjo, 2006, Analisis Laporan Keuangan pada Perusahaan Agribisnis PD. Berkah Alam, Jurnal MPI, Volume 1 nomor 2

Harahap, Sofyan Syafri. 2011. Analisis Kritis atas Laporan Keuangan. PT. Raja Grafindo Persada. Jakarta

Kabupaten Bone Dalam Angka 2018, Badan Pusat Statistik Kab. Bone,Sulawesi Selatan, 2015, https://sulsel.bps.go.id/ 
Kesuma, Yolanda Fatrecia, 2014, Analisis Laporan Keuangan Sebagai Dasar Dalam Penilaian Kinerja Keuangan PT. Budi Satria Wahana Motor, Jurnal Akuntansi dan Keuangan, Volume 5 Nomor 1 Hal. 93-121

Maith, Hendry Andres, 2013, Analisis Laporan Keuangan Dalam Mengukur Kinerja Keuangan Pada PT. HANJAYA MANDALA SAMPOERNA TBK, Jurnal EMBA, Vol.1 No.3, Hal. 619-628

Pawestri, Noristera, 2018 Sebanyak 72 Persen UMKM Belum Terfasilitasi KUR, http://jogja.tribunnews.com/2018, diunduh tgl 28 Agustus 2018

Susilo, Bambang. 2009. Analisa Laporan Keuangan untuk Menilai Kinerja Keuangan Perusahaan. Skripsi. Universitas Muhammadiyah. Surakarta.

Trianto, Anton, 2017, Analisis Laporan Keuangan Sebagai Alat Untuk Menilai Kinerja Keuangan Perusahaa Pada PT. Bukit Asam (Persero) TBK Tanjung Enim, Jurnal IImiah Ekonomi Global Saat ini, Volume 8 Nomor 3, Hal. 1-10

Gunawan, B.I. (2017), The Influence of Exotic Service Quality Towards Overall Satisfaction at Hotels in Makassar. New Delhi: Serialjournals. 